\title{
Marja Gadomska
}

\section{ZAIEZNOSCI MIEDZY MRESCIA A FORML GRAITCZNA}

W EDYCJACH POEZ JI Z PRZELORU XIX \& $X X$ WIEKU

Prze?on XIX I XX wieku by 1 okresem szczególnie parysinym dia rozwoju ks1ązkt. "i miej przede wsmystrtm majazky odblote nowe prąy 1itoxacirle 1 axtystyczne tlzodej Po.ski. Szozejóng rolę odegrała poesja /xixyka/, będąca wówczas gaturik1em 11terackxm, który - obucizony z pozytywistyczxe go úpienia - przezywał burz-

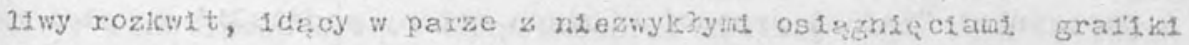
1 typografil artystycznej.

Ze vzględu na speoyilozny charakter 1 funteje poezj1, sztuka jed vydrwanka jest szozegbinfe stcomplikowana. Mro to, a moze waśnje dlatego, stanowl ona "poletko doświadczazne" dla nowjoh prędó artystyoznych. Prześledzenıe n1ekt6rych cech książí ha pxzykzadach wydanych wtedy tomkkóm poezjl pozwo?1, no1m adenien, na pewne porównywazne uggóntenıa. Omowlenıe rozwoju 1. lośctowego 1 jakosc1owego produkoj1 wydewncaej w latach 1390-1914, prze-

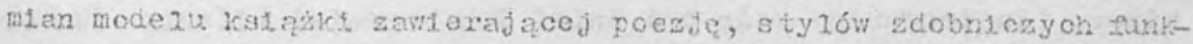
cjonujacyoh w owyin canglo wykraczeloby noza ramy artytcuzu'. W tym mejsou chelałebym przedstarkó próbe strukturained intexpretacji edyoji poetyckich przekonu XIX 1 xX wieku.

Jedrym a postuzatóm mrodej poxsh było dązente do syatezy

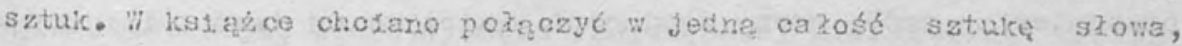
satukę 1lustracj1 1 sztuke druku. Jażono wówezas do podporząckorania wszelkich dzhałan kanonou estetykL. Oezywície zwiazici. formy graticznej a treśclę poezjl nozna nozpatrywab wedzug róznych kryteriów. Jednym z nich, uznawarym dass za podstawome, jest krytexium zgodności semiotycznej. Na przezomie XIX I XX wieku nie użymano tego pojecia, ale intuicyjne niejako dęzono do jego reallzacji. " rzeczywistośl bowleu, jaiktolwiek tak nie nazywana, zgodroś semiotyezna funkojonowała jako postulat, już w tym okrea1e. Była ona realizomena przez zsodnośs: 
1/ treśl 1lustraoj1 z treścią wiersza,

2/ nastroju vywolywanego przez wiersz 1 nastroju jego zdobniotwa,

3/ formy /stylu epok1/ szaty graficznej wiersza.

Mieczys kaw Wallis podaje kilka definicji ułatwiających lepsze zrozumienie analizowanych tu problemów. "Ktoś ksztaltuje przy ponocy pędz11, farb 1 płótna pewien zespół plam barvinych, zeby w odbiorcy mywołać wyobrażenje konia, dzlękj temu, że między tym zespołem plam barwnych a konjer zachodz1 podobleństwo wyglądu: jest to przedstawianie bezpośrednie. Ktos inny pisze lub wymawia wyraz «koń , żeby wywołá́ w odbiorcy wyobrazenie lub pojęc1e konia dzlęki pewnemu zwyczajowl języka polsk1ego: jest tio przedstawlanıe pośrednie. Ktos jeszcze inny maluje Iwa, żeby wywołać w odbiorcy dzlęk1. stosunkowi przedmlotu do cechy 1 dzlęk1 pewnej konwencji pojęcla siky: jest to przedstamianie symbolicane" 2 . A następnie: "Sztuki przedstawiające możemy podzıelı́ a kolei na sztuk1 przedstawiające bezpośrednio 1 sztuk1 przedstawiające pośrednio $w$ zależnośl od tego, czy posługują się one przedstawian1em bezpośredniti, czy pośrednini. Do sutuk przedstawiajęcyeh bezr pośrednio należą: rzé́ba, malarstwo, grafika, pantonima,

filin niery. Sztuka przedstaviająca pośrednlo jest poezja" ${ }^{3}$. I dalej: "Z dziełami sztuk przedistawiających pośrednio łącz̨ się niekiedy dzieła sztuk przedstaw1ajęcych bezpośredn1o. halarze 1ub grafl cy 《1 Iustrują》 utwory poetyokie, przy czym stosunek 12ustracj1. do utworu 1 lustrowanego może byó miniej lub bardziej blisk1. Widomą oznakę takiego połączenia dzieła przedstawiającego pośrednio 1. dziez przedstawlających bezposrednio jest często zespolenie tekstu 1 1lustraoj1 w Jednym przedruocle flzycanym - księże $11 u-$ strowanej"4. Przytoczone cytaty pomog̨̨ usystematyzowaó niżej zaprezentowaną próbę oceny z godnosci selolotycznej trescel 1 formy $w$ mrodopolskich tomikach poezji. "W okxesie lizodej Polski ów stosunek dzlez przedstawiającyoh pośredn10 1 bezpó́rednio rysuje s1ę szozególnie vyrá́nie. Wożna go prześzedz1é w wydtanyoh wtedy tomikach poezj1. Kierująo się tymi zasadami opisywane poniżej przyikłady podzieliłam na kıłka grup. Granice podziałów są dość plynne 1 niezupeznie jednoznaczne, jednak dla zobrazowanla zagadnienía przyjęcie schematycznych kryteriów porządkowanla stało się ntezbędne. I tak: 
I. Pozycje wykazujące zgodność semiotyczną:

1. Z godnoés tresciowa:

a/ poezja powstajęca do fotowych obrazów,

b/ 1lustracje mogęce zastąplé konkretny eragment tekstu,

c/ 1lustracje będące próbą 1nterpretacj1 tekstu, ale nie odblegajęce od jego treśc1,

d/ symbollozne teksty i symboliczne 1lustracje / $w$ duchu symbol1zmu miodopolskiego/,

e/ 1 iustracje $z_{\text {godne }} \mathrm{z}$ treściz wiexszy, stylem artystycanym 1 nastrojem oraz 1deg sztuki narodowej.

2. Zgodność nastroju:

a/ obrazy zgodne z nastrojen utwork, ale nie będz̨ce 1.lustraJę do niego,

b/ 1 lustracje z godne a nastrojem 1 tematyka utworu, are stanowlące dodatkowy "nizekaz" na dany temat,

c/ 1. iustracje bẹąoe uzupezníeniem artystyeznya tonu 1 twóxczoscas autora wierszy,

d/ vinsetis zgodne z nastrojem 1 typew wierszy.

3. Zgodność forny:

a) Winietiki wykazujące jedynie zgodność lorny,

b/ toniki poezjí posbavione ozdób.

II. Tcmik1 nte rykazujece z godności selulotycznej:

af niezgodnosé tresios,

b/ nezgodnosú formy.

I.1.a.

Zw1ązk1. 1 1ustrac'j z tekstem sa na jbuższe wówczas, gdy autox tekstu tworzy 1 go do gotowych juz 1]ustracj1. "wyraźnie uwidacznia sie to w przypadku ksiązek dia dzlecl pisaxych przez lharie Konopniekz 1 Artura Opphans. Układall on wiexsze do zagranioznych 1lustracji, które wyduwca /najozęściej Michał Arct/ dostarcaaz autorom.

Kolorowe obrakk szwedzkiej autork1 i 1lustratork1 książek dla dzieci - Elsy Beskow, stały sie kanwą księżi Or-ota "H1storle o grzybowy ch Ludiach" 5 . Na jej treśc sik lada się cykl wierszy pośw1ęconych łuakom zamıeszkującyn różne gatunk1 grzybów. Rysunk1 grzybúi sq̨ tak real1styezne, że mogạ skuźý do rozpoznawanıa poszcze gónych gatunków wystepujących w przyrodz1e. Ludk1 upo dabniaja się do ulubionego grzyba przez czapeczki lub ubranka odrowiedniego koloru. Treśs wienszy do tego stopnia jest wierna 
1.ustracj1, że autor nıe pomjja nawet informacj1 o tya, że królewskie berło by $\geq 0 \mathrm{z}$ makówkt albo, że plesek grzybowych panienek to żuczek na smyczy. Opis obrazka zmusza więc czyteln1ka do zelbawy w poszuks.wanie wrytych szcze gózów I sprawdzanıa, ozy autor czegó́ nle pominąx. Poeta by z. jednak bardzo dok kadny. Zdarzyz mu slę ty2ko jeden droony błąd. Otó zmęczona rodzina zudków odpcczywa pod erzybem, któxy oppman uznaz za rzeczywistośc1 - sądząc z rysunku - grzybetn tym jest kansa / zepiota procere/. grzybon yoh opjeirke. it czubajke

Do 1. Iustracj1. Elsy Beskow Harla Konopns cica nap Lsaza popularną do dzís opowiastke "Na Jagody" . Konopnioka twoxzyla takie wiexsze do sztychów anglelekich, kohorowjoh chromolztogrami Denry Benneta 1 imaych. Do gotowych 12ustraoji napleaża zxang̨ xúwnieź histome "o Janku "egdrowiczivu"? Ryciny se wyrainie pochodze-

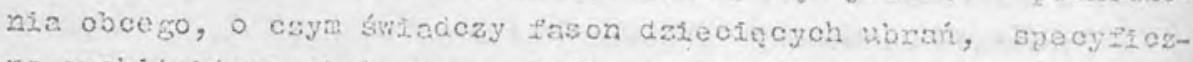
na architektura wiatraica, podróte na osiokku. Jaustracje przedstawiada Janica w rósnyoh sytuacjach podozas nie zanowiedzianej

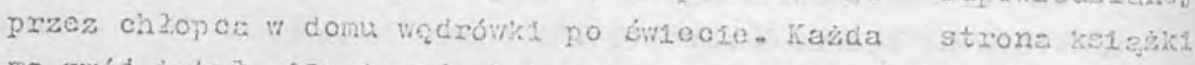
ma swóf tytuk, 1lustracje t tekst rozmieszczony dotoka rysunkl. Rysunk1. 1 wiersze stanow1? odręune cakośch powiszane osobz 1 10sanf. Jakka.

Wlersae Konopnickiej nie trayraja sle tak ścilie 12ustracji jak teiksty Oppmana. Kutorka caesto przedstaws a mysis 1 rozmowy

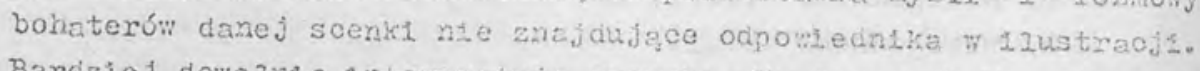
Bardzief dowolnze interpretuje rysumk1. W wierszach do cklinyoh I sentymentainych rysunicó: Henxy Benneta, praedstariajajcych dejecl a "dobryoh donón", w sielankowys krajobrazle - prackazuje ona treśc1 torailatorskie 1 dydaictyozne typowe dia więiszosol utworów il terackioh aciresowanych do dzLeol w ted epoce.

odmlenna jest wymowa poezjl przeznaczonej dia dorosiych, a opartej na jotowych juz rycinach. Poemat "Wojna"8 powstaz na motywach cyk Iu Grottgera pod tym samym tyuulem. ": iatach 1866-1867 Artur Grottger narysowaz 12 piansz będecych romantyczne wizje grozy woiny. Konopnicka dopisala do nich pacylistycany apel do ludzkosc1 w formie wiersza. Byž poematem o duchomych clempleniach twórcy /poety, malarza/, któremu aniok przypomiensa plękna kobieta z swiazdą nad czolem - Ukazuje kolejno zwiastuny wojny, rozpacz matek, któryoh synowle wyruszają do walki, niedolę sierot, głód, pożary, nieludzkie zachowanie kobiet okradaja- 
cych zwloki pozegzych, zbeszczeszczony kośc16ł. Artysta zostaje wreszcle sam, pamięta wizje, rysuje to co zobaczyz 1 przeklina ród ludik1 - ród Kaśna.

Dosć swobodna interoretację zaprezentowaza Zofla Gordzialkowska w oyklu wierszy poíwięconych obrazom Bbcklina?. Szwajcarski malarz Axnold BYcklin nadawal znaczenle symbollczne swoIm neororantycznym obrazom o tematyce fantastycznej, a Gordzlazkowska próbowała to znaczenle wyjaśntć. Na przykzad powszechnte znany "Autoportret ze smiercia" przedstamia zamyślonego, zasluchanego malarza $z$ paletą 1 pędzlem $w$ dłonı oraz śmieró grajęca na sicrzypcach. WLersz sugeruje, że Émieró stojęca za maLarzem gra p1eśn szkiejetów i przekonuje artystę, że tworzenie aie ma sensu, bo ona panujac nad wszystikim 1 tak wszystko $w$ proch obróo1. Malarz przez chivile sžucha, aź wreszcie odpędza ínteró przeszkadzajęç̨ mu malować. Autorka wiersza przyznaje słusznosć Buck21nowi, twlerdząc, że twórozośc trwa teź po śmierc1 malaxza, a jego obrazy madal 1msplrują 1nnych.

W tym tomtiku poetka undesc1 da mięzy innymi wi ersz thumaczący alegoryczny obraz "poezja I Nalarstwo", a przedstawlający dwie kobiety $w$ powiewaych szatach czerpięce wode ze znajdującej słę mjędzy nimi fontanny. "Wiensz wyjałnia genezę sytuacj1: otóz po stworzeniu śwlata $B \sigma_{z}$ by 1 niezupeinie zacionolony ze swojego dzieła. Níe podobała ru się panujęca wokóz olsza l diatego daz zleml. glos /ryk morskion fal, splew ptakón, szum las6w/. A potem stworzyz "One" - symbolizujęce Poezję 1 Vialarstwo, które, spotkawszy się u źródka /natchnienı?/, rzekły:

"Jedna wiedzie nas droga, Jeden polot ducha, tyzko twoja mýs patrzy, a moja mysz sucha".

Odrębny rodzaj dostosowywanta tekstów do gुotowych obrazbw stanowi xy cykle wlerszy z podrózy. Byzy poparte wiasnym1 wsponnieniami autorów, a także pocztówkaml 1 fotograłlami odpowlednich mlejsc. Ten typ reprezentuje np. Wlersze Wkadyskawa Bukowińskiego "lia grecklej fal1"10. Autor relacjonuje morską poorb́z mokóz wybrzeży Grecj1, podziw1a krajobrazy, przekazuje wlasne odozucla w sposób śwI adozący o zmajomośl histori1 i kultury Grecji. Ilustrują ten tomik fotogralle wspóxozesnej Grecji 1 jej zabytków /Akropol, Partenon, Salanına, Moxze Egejsicle/. N1ektóre adjęc1a, nie będące dokładnyml odpowi ednikami treśc1 wierszy, mprowadzają czyte inika w irlimat 1 odpowiedni nastrój, pozwalają mu zatwiej wyobrazló sobie podróż 1 refleksje poety. 
Podobną metodę stosuje autor "Ilustrowanych sonetów rzymskich"11. Kaźdemu sonetowi odpowlada fotograf1a op 1sywanego zabytku /Panteon, Kopuła Bazyl1ki sw. Plotra, Forum Romanum, Forum Trajanum, "Przemienlenle Pańskie" Rafaela 1tp.l umieszozona na sąsiedniej stronie. W tym przypadku zalstniała pełna zjodność fotografii z treścį wiersza.

I. $1 . \mathrm{b}$.

Adekwatne przedstawienta treśc1 wierszy przez 1lustracje występuję zw Łaszcza w poezì stanowiącej "św1ętość narodową", a 1 lustrowanej przez twórców wychowanych w duchu mazarstwa real1styozmego, historycznego. I Iustratorzy zmierzal1 do dokzadnego przedstawianıa tré́cl 1 udokurentowania tej wiernoścl prizez podpisywanie 1 Iustracj1. fragmentam 1 poezjl.

Na przykzad jedna z 1 lustracj1 Jullusza Kossaka do "Konrada Wallenrode" 12 Adana li okiewıcza przedstawia Krzyżaka na koniu,

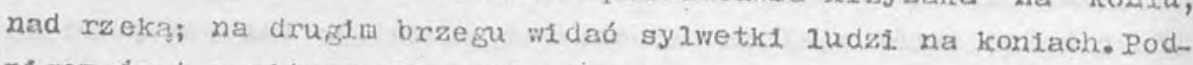
p1sem jest poniższy fraguent wiersza:

"Po drugiej stronie, w szyszaku 1 abrol

Nierilec na koniu nleruchomy stol.

Cczy utkw1wszy w aieprzyjaciox szaniec,

Nabija strzelbę $111 \mathrm{czy}$ różantec".

Równ1eż 1lustracje Kossaka do "Pleśn1 Leglonow"13 sę dok kadnym przedstawien工em poszczególny ch strof Nazurka Dąbrowskiego. Na przykład fragment:

$$
\begin{aligned}
& \text { "Liarsz, marsz Dąbrowsk1, } \\
& \text { z ziem1 w2oskiej do Polsk1" }
\end{aligned}
$$

stanowi podpls pod rysunkiem przedstawlającym generała Henryka Dąbrowskiego na czele Legionów wskazującego szablą klerunek marszu.

Realistyczne 1 moźlivie wiernie oddające tresó utworów by zy 1ustraoje wykonane do "Dzie $\}^{114}$ Juliusza Słowackiego. Ta edycja była 1lustrowana przez wielu malarzy /Henryk Plątkowski, Stan1sław Masłowski, Zy guunt Badowsk1, Stanisław Sawiczewsk1, Antoni Gawinsk1, Józef Ryszkiew1oz, Konstanty Górski, Wacław Paw liszak/, a wszyscy zrobili to z pletyzmem dla słów wieszaza 1 torską 0 szczegóry.

Konwencja artystyczna wymagała wówozas, aby nłe łączyć nowatorstwa plastycznego a tekstam 1 stanowlącym1 kanon 11teratury narodowej. Stosowali się do tego równleż malarze, którzy pó́niej 
zasłynęl1 jako twórcy llustracj1 w stylu mlodopolskim. Na przyk lad Stanıs Law Dębiok1 1lustrował "Splewy historyczne" 15 Juliana Ursyna Niemcewicza. Portrety władców Polski, którym Dośw1ęcone by ky poszczegóne stroly, wykonane zostały piórkiem, z du¿̇ę starannością, dbałością o św1atłocíen i trójwymlarowość, lecz n1ezwykie statycznie. Haja one wiele cech wspólnych z "Pocztem kró Ióm polskıch" Jana Matejki. Trudro jednak stwierdaí́ ozy Dębick1 aź tak ule gal wp ływom artystycznym Matejki, czy mośe chodziło tu o zgodność portretón z wyobrażeniami społeczeństwa o poszczególnych władcach wytworzonymi juś przez rysunki Jana Mate.jki.

Podobnie ilustrowano kIasykę dydaktyczned literatury dziec1.ęcej. "bajk1 1 povf astk1" $/ 1890,1900 / 16$ Staniskawa Jachow1cza by zy 1 lustrowane 24 draeworytami ws projektow Juliusza Kossaka, Wojclecha Gersona, Hugues'a P 1oarda, Henryka P11latiego Iw wyoan1u z 1900 r. drzeworyty powtarzają s1ę 1 sq uzune intone codatkowy zestawen podobnych ry oln nieznanych autcrów/. Dziec1. przedstawione na ryoinach charakteryzujac się "ytrzeszozonymi oczaul, bearysjuyu wyrazen twarzy oraz pozę zastysłą w bezruchu. Zachodzl tu aiewątpliwa, choć może nie w pełas zamierzona, zgodność semiotyczna mśdzy treśc1ą 1 formą wiersza, stylem 1

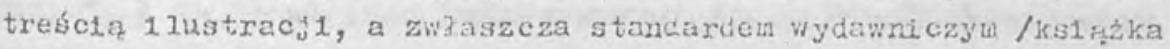
zostala vydana na gasetowyr papierze, niestarannie wydruicovana granetową faxba - jest to tanie wydawrictwo masowe/. Ilustracje sq̨ zgodue z treściz wierszy, ale $1 \mathrm{ch}$ forma świadczy o dośc powierzchownym stosunku axtystow do powierzone go im zadania.

Oczywíscle taka ocena ksiązeozk1 jest możliwa z perspektywy lat osiemdziesiątych XX wieku. Jednak na przezonie XIX 1 XX wieku podobne książeczki być może nle razily niczyjego poczucla estetyk1. Byzy typowe dia owej epoki, a przez swoją tamiość miazy byó dostępne dia wieju 1 oddziazywá na szerokfe rzesze czyteln 1 ków.

"ychowawczą ks1ązką d la dziecs. by 1 równ1eż "Katechizm po1sklego dziecka" 17 "Xadysława Bełzy. Byz to zbióx popularnych wierszy uczących daleol patriotyzam 1 religljnośc1. W $1913 \mathrm{r}$. ukazax się jako nlestaranne 1 tanie wydawnictwo nasowe, ale wcześniej - w 1912 roku, ta sama pozycja została wydana z 11ustracjarni Józefa Vẹclny-Krzesza. Kolorowe liustracje to reprodukcje akware 1 nosą̧oych cechy inpresjonlzmu, wykonane przez 
malarza real1stę 1 przedstawiające treś́ poszczególnych wierszy. Na przykzad 1 lustraoja do w1ersza Modiltwa pozsk1ego dziewczęola", będącego modiltwą małej polskiej dziewczynki proszącej Boga o błogosławl ef́stwo dla Ojczyzny, przedstawia klęcząoa dziewczynkę - na dywanlku przy zóżku - przez obrazem latki Bosklej Częstochowskiej. Reprodukoja obrazu wisi na sclanie, a ustawlone obok kwiaty tworze mały oxtarzyk; jdzieś z boku pada świ atro ośletlające całość. W przypadku tego tomıku artystyczna wartość liustracji jest zapewa wyższa ni.j wartość dydaktycznych wierszyków。

Każdy utwór poetyck1 oplera sie na pewnej korwencfl artystyoznej 1 - podobnie jak każde dzieio sztuki /ir tym ilustrajjal jest téz wynıkjem jakıejś umowy. Tutaj zgodnoś konwencji jest zachonana. Wspólnę cechą tomików tej grupy są 1 Iustracje dokładnie przedstawi ające treśc wiersza. Jiustracja jest uzupeznieniem tekstu, a rawet ñe tyle uzupełnieniem, 1le elementem, wóry móglby zastap 16 wyrwany fraguent, co áwiadcry o z godności semlotycanej. Ant w tekstach, an1 w Llustracjach omavianego typu nie ma śladón symbolızmu charakterystycznego ala przełomu XIX 1 XX wieku. Tu wszystko jest jesne, proste, zrozumiaie dla kaźdego Inawet symbole stosowane w poezji romantyoznej by zy powszechnie rozuníane/. I Iustracje by zy statyczne, realjstyczne, Ich twórcy ogromnie dbali o trójwymiarowośc, glębię rysunku, śwlatłocień 1. nie pozwalali sobie na żadne odstepstwa od tekstu.

I. 1.9 .

Na pograniczu llustracji i tekstów operujqcych symbolami /w rozunieniu symbolizmu młodopolskiego/ i tych ozysto realistycznych są pozycje, w których 1lustracja stanow1 integralną częśb utworu, dodająo mu ekspresji. Nadawało to nieco inne, żywsze zabarwienie treśl wiersza 1 podkreślało - na ogól żartobliwy charakter utworu, bo najczęściej w poezj1 komicznej pojawiają ste takie 1lustracje.

Rysunki ekspresyjne, zgodne z treśc1e, ale bez symbol1ki, posługujące się jedynıe bardzo dynamiczną kreską eksponującą pewne cechy bohaterów rysunku, występują choclażby w bajce Juliusza Slowacklego "0 Janku co psom szyz buty"18. Trescla bajk1 są perypetie chłopca, który nie chclał się uczyé, uciekı navet z terminu od szewca 1 postanow1 2 popynád w świat. Znalazł się na niezrianej wysp1e. W czasie rozmowy z królem pochwalił się, jak 
áwletnie potral1 szyó psom buty. Został zaangaźowany do pracy 1 tak dobrze wywiązal się z powierzonego mu zadania, że za catery dni charty poszły na polowanie w nowych butach. Fabula bajki została zilustrowane przez Antoniego Gawińskiego. Rysunek będący 1lustraoją do rozmowy Janka z królen 1 jego świł wia małego chłopca przyglądającego s1ę dużym dorosłym z szacunklem, ale 1 niepohamowanz dzlecįç̨ ciekawośc1̨̨. Król 1 jego dostojnloy, wszyscy poważni, w wlelkich okularach, z zalnteresowantera 1 wyclągntętymi szyjamı oglądają Janka. Kro1 na cienk1ch nogach ma skarpety haftowane $w$ królewskie korony, oo jest dodatkowym elementem koml cznym. Cechy postacl są celowo przerysowane, Edyż to dodaje rysunkom dynamizmu 1 życı. Pełen wesolości klinat 1lustracj1 jest zgodny z żartobliwą opowiastką Słowacktego.

Bajka d la dzieci jest "pan Twardowsk1"19 Lucjana Rydla z 1lustracjani Antoniego Procajlow1 cza. Tress bajk1 stanows znana opowieśc o mistrzu Iwardowskim - ubogim szlaohoicu, kształconym w Krakowie 1 jego kłopotach ze zlq żonę. Sposobem na utraplenia mało byé podplsanio paktu $z$ diabkem, a tym samym mozilwośs mykonywanla wszelkich ni eprawdopodobnych sztuczek. Diabez, zniecierpl1wiony pomysian 1 Twardowskiego, sprowadz1 3 go do karcamy "Rzym". I tu Rydel jako jedna z wersji dalszych losów swojego bohatexa przytoczył całą balladę Adama kioklewıcza "Panf Twardowska", ale według nlego 10sy Twardowskiego potoczyy sle inaczej - mianowicie zostal porwany przez diabla 1. unieszozony na księżyou.

Rysunk1 do tej opowiastk1 są kolorowe, zecz na nlezbyt wysokim poziomie technicznym. Należy zaznaczyó, że książka była drukowana w Warszawle. Sg to początk1 kolorowej 1uustracj1 na zlemiach polskich, ale świadczą o tym, ż już wtedy usizowano rob1ó własne chromol1tografle bez oględania sie na szwedzkie, anglelskie czy niemieckle vzory. Postaole na rysunkach są trochę przerysowane, lekko karykaturaine, ale niezwykle dynaniczne. Dobrze oddają nastrój wiersza. Ryc1ny 1 treśó stanow1ą tu żodna strukturę mająç̨ służyó zabaw1e, a także styłowo przekzzać starą polską legendę.

Poważniejszę pozycją w tej grup1e jest "Czarodzlejskie w1ano" ${ }^{20}$ Valentego Zielińskiego. Autor 1lustracj1 - Standsław J. Koz kowsk1 - nie tłumaczy tekstu, lecz go 11ustruje. N1e podejmuje 
sle daleko Idące j interpretacji tekstu ze wszech miax symbolicznego. Baśn, bo jest to baśn dla dorosłych, opowlada o panstwie clemnośo1 1 zacofania. Król tej kra1ny uważa, że tylko prawdziwa clemnoś́ panująca nad krajem może zapewn1ó trwałośó królestwa. Zbuntowany następca tronu z rozkazu ojoa opuszcza kraj. Trafia do państwa jasnośc1, gdz1e wszyscy są szczęśl1w1. Królewicz c1emnoścl zakochuje sie a wajemnoścla w królewnie jasności, postanawia pojąć ją za żonę 1 powróció do swojej ojozyzny. Król jasności oflarowuje młodym szkatułkę zaczarowanych klejnotów mających rozświetl1é krainę olemnośol. W krainle clemnośc1 zaczarowane klejnoty spowodowały znlkriegole olemaych chmur 1 zka, a mieszkańcy z entuzjazmem pow1tal1 mર̊odego króla. Ekspresyjne rysunkl zgodne z symboliką wiersza 1lustrują go, wnosząc pevmą płynnosó nastroju, co jest swolstą interpretacja, nie odbiegajaca jednak od tekstu. Przesłanie tekstu wspomagane jest efektem pracy jrafika. Na przykıad 1Lustracja do fragmentu opisujęcego ciemność, szarość 1 ponury klimat państwa clemnośc1 jest mroczna, przedstaw1a miasto spowite skłębionym 1 chmuram1. Jedyną własną Interpretacja 1lustratora jest przedstawienje królewicza ciemności i jasnej królewny w postaci prayjaznych sobie an1oxów. Walka dobra /jasność ze złem /olemnośc/ przeble ga lagodnie. Wystarczy tylko chcieb, aby dobro, mądrośc, Jasnosó zwyoiężyzy i Katwiej tego dokoná́ miłością niż nlenawiśclą. Mcg̨ to osiągnąć mrodz1 - c1, ktorzy nie boją się zm1an 1 ryzyka. I.1.d.

Z Jawisko zgodnoścl Iub tłumaczenla symbol1 często występowaxo w poezji 1 grafice mzodopolskiej.

Pewlen typ symbolu wykorzystał Zy gmunt Ryszard Kamińsk1 11ustrując "poemat cyniczny" Stanislawa M. Lewina "D on Juan redivivus" 21 . I lustracje są groteskowe, ozuje się w nich rękę karykaturzysty - lekką 1 clętą. Stanow1ą one w poemacle odrębne dz1eło sztuki, mimo że są treściowo związane z tekstem.

Tresolą utworu jest historia liarcyza - dandysa 1 uwodz1c1ela pragnącego ożenı́ó się z panną na1wną 1 nlew1nną, aby pod płaszczykiem nienagannego małżeństwa móc spotyká́ slę ze swymi dawnymI 1 nowymi kochankami.

Zygmunt Kamiński operuje czarną linią na białym tie. Nie ma tu ani śwlatłocienia, an1 trójwymlarowośc1, an1 perspektywy. Jest natomlast pełna wdzięku ekspresja, karykatura 1 znieksztaxcenie 
postaci, które nadaje 1m wyrazistych cech charakteru. Narcyz to elegant, w smokıngu, cylındrze, z laseczka, monoklem, podkręconym wąsem. Na jednej z 1lustracj1 gestem pe znym zn1eclerpliwienla 1 znudzenla, ale nle pozbawlonym axystokratycznej elegancj1 odrzuca zrozpaczone damskie serca. Moment samobojozej śmiercl N1ny /dawnej kochanki Narcyza/, która wy glądała "jak z sewrskiej porcelany f1gurynka" / krynolinie, upudrowanej peruce 1 maseczce na twarzy/ jest także symbol1czny. N1oda kobieta w wleczorowej suicn1 leży w salonie. Nad nlą pochyla slę kosclotrup w cylindrze - smieré, z klel1szklem /może trucızny/ w ręku, a jej z zowleszozy chlchot wydaje s1e byé slyszainy. Powtarzająca sie winietke, pozorn1e nle zw1ązaną z treścia, stanowi laska błazeńska $z$ dzwoneczkamı. Jest ona jednak symbolem cynımu, żartu, w1sielczego humoru - tego, co przewija s1e między wienszami w treso1 poematu.

Symbollzm w treśc1 I ekspresjonistyozne ujęc1e pojawia sie w tomiku "Poezj1" 22 Eduunda E1edera. Dwie

1 Iustracj1 styczne 12ustracje do tej ksląki wykonane przez Ludw1ka llachaiskiego przypominaja klimatem rysunk Wojclecha Welssa. Zawarte " nich symbole podkresia forma. Ilustracja do wiersza "Idziemy" przedstawia grupę naglch mężzyzn zakrywajzcych oczy dłońm; miedzy nim1 snuja się pasma mgży. Mężzyźni 1dą przygarb1en1, smutni, jakby nie wiedzleli dokęd, bez celu, Rysunek nesie bardzo duży zadunek emocjonainy /melancholla, braik nadzle1/, a jego interpretacja narzuca się sama - to życle gdzieś nas pcha, ży jemy, ale nie znamy przyszłoscl, nie wiemy, co nas czeka. W terániejszośc jest nam także źle - smutno, ponuro 1 z jodnie $z$ nastrojamI dekadentyzmu n10 nas od tego nie może wyzwous. A oto fragmenty wlersza:

"Idziemy smętri, c1si, zadumani,

Serca wiecaysta rozplera nam żałośc,

Idziemy migami ciemnems owian1,

I wIdzIm nędzę Istnlenıa I mazość. $1 \ldots 1$

Idz1emy smetni, c1si, zrozpaczeni, N1e wieny dokad 1 po co nie wiemy, Nad nami nie ma słonecznych promieni, A my $1 d z 1$ emy ... gdzieś ... w bezkres 1dziemy". 
Interpretacja tresci wiersza jest 1dentyczna jak wymowa 11u$\operatorname{stracji} 1^{23}$.

Grafikiem, który najlepiej wśród wspózozesnych ozul ducha sambol1ziu byz Edward Okun. Jego Ilustracje do poematu Kasprowioza "Mi lośc" I do "Hstrza Mwarciowsklego" Staffa są przykíadem symbolicznego komentarza do symbolicanejo tekstu. Interpretacja Okunia nle zawsze jest dz1ś czytelna, ale jest to zgodne z zażożenlami symbolizmu epoks Mzodej Polsk1. Definioję symbolu przeromu XIX 1 XX wieku, opracowang zi podstawie pism teoretyczxych tego prądu, podaje Nar1a podraza-Iwiatkowska: "Symbol jest to Indywidualny, niekonwenojonalny, Dozbawlony funkojl pedagogiczrej, a także funkcji ormamentacyjnej, wieloznaczny 1 nieprecyzyiny, na sugerowaniu okreslonyoh wzmszeń operty odpowiednik takich jakośl, które n1e bẹdac jakosolami skrystalizowanym, nie posiadaja adekwatnych okxesleŕ $w$ systeme jęykowyra. Symbol taki poszerzony na szeres obrazów 1 araloibli, a niekiedy na cazy utwór, na skutek kompletnego zlania się marstwy znaku I znaczenta może stad́ slę byten autonom1aznym nie podiegającym tzumacomiu na jezyk dyskursymy" ${ }^{24}$.

"1:-2zosó" 25 Jana Kasprow1cza jest cyklem wierszy powjązanyoh tematyczn1e. Ilustracja Oicunia do wiersze "I' amore desperato" przedstawla drzewo, którego pleń stanowi clazo aaglej koblety. Jej rece, podobale jak wlosy, przeradzają sie $w$ ukwleoone gaZęzle, nogl, aź co biodex, to poskrẹcana, węzlasta kora drzewa. Nagi mężzyzna, usizujacy desperacko przytrzymad sie ciaza tej kob1ety, jest od ntej sizę odrywany przez smieró /kosclotrup w chažac1e/. Wlersz opowiada o tę̇żzýnie, który kochając kobietę uświadomiz sobie, że mfzośé flzyezna mu nie wystaroza. Przestal Ja kochać, odszedr od niej duchowo, a zakochana kobleta nie zmíszszy tego umarza. Dop1ero wtedy mézozyzaa zrozumiaz, że ona byza dia nIego wszystkim. Poeta utożsamla w jednej postaci. mizość, śmieré 1 kobietę. Wszystkie trzy są oczekiwane 1 zaienawidzone, ale nieucironme. Symbole $v$ vierszu 1 rysunku nieodmiennie wskazują na motyw ozzowieka rozdartego między źjoiem a śmierclą. Posiadając śwladomośc niouniknonego clemplenta 1 śmierci, cz zowıek pragnie żyé jak najdzużej, gdyż życie to tak-
że mizoś.

Inny "fersz - "Przy szumfe drzew" nów1 o męźczyźnte I kob1ec1e, ktorzy w les1e próbowal1 wyznád soble nilłoś, leoz nie 
mieli śmiałośc1. Ich, a wraściwie jego rozmyślanla 1 jej reakcje stanowį̨ większą częś́ utworu. Pocałunek pozwoli l im na ujawnienie bez słow skrywanych dotąd uczhé I jednocześnie stał sie symbolem czystej mikośo1. Rysunkowl Okunia najbardziej odpowi ada poniższy fragment wiersza:

"W wiezkiej świątyni przyrody, pod niebios

Jasnem skiepieniem, w z1elonym

Lesie, wyrosłym na łagodnym wzgorzu

Przy drzew poszumie zawarkem z nıą sluby ..."

Rysunek przedstawia całującę s1ę parę. Długle, rozpuszczone wlosy kobiety przekształoają s1ę w struny leżącej obok 11ry. Mężczyzna wychyla się jakby zza drzew - z brzozowego gaju. Symbole tu ukryte to IIra - oznaczająca poezję, f́plew mizosc1; brzozowy las - symbol życia; biel drzew - niewinność uczuó, a pocazunek to spełnienie m1łosc1. Rysunk1 Okunia charakteryzuje falista, płynna linla, która często przechodzl kagodnte z jednego przedmiotu w inny. Sa płaskie 1 dwuwymiarowe, o typowej secesyjnej dekoracyjnośc1.

Podobny styl prezentują 1 Iustracje o "Mistrza Twardowskiego" 26 Leopolda Staffa. Do każego śplewu okuń wyiconaz odrębą 12ustrację - tzw. Śródtytuz 1 mały In1ojał będący równLeż swo1stą ilustracją. Tekst v1ersza 1 treśb rysunków są symbol1ozne. Twardowsk1. nie jest tu typowym sarmata, jak w wierszu Rydla. Jest czlowlekiem nie rozurianym przez otoczenie. To clemny zud wymyślaz o nim przeróżne, nieprawdopodobne historie - Jak choclaźby opowieśc o pakcie $z$ diabłem. W rzeozyw1stośc1 Twardowski chclal zrob1ó coś, co da zabiedzonym 1 umęczonym ludziom szczęście. Zamknąl się w wieży, aby tam pozná́ możliwą dostępną viedzę. A hardzi, podburzeni przez zawistnego znachora ludzie wygnali Twardowsklego $z$ dworu ognjem 1 egzorcyzmami, zaszczul1 też kobietę, którą kochaz. Twardowski uznaz, że jego najwyższym bóstwem będzle dusza 1 ona da mu syna - Czyn. Byl szozęsliwy 1 cholal hú 1nnym szczęśc1e. Zrozumial jednak, ze ludzıe z jego ws1 nie mogą dostad́ szczęścia, bo jeszcze bardziej zgnuśnieja, że muszą je sobie sami wypracować. Zniknął, a ciemny lud opowiadak, że szatan porwal1 go I wtopil1 w 16 d Księżyca. Tymczasem Twardowsk1 siedzlał na skale nad morzem i rozmyslal, czekając na Hoc, która znów go wezwie. Niestety, Moc, która nie zawsze jest poskuszna 1 nie każdemu, od Twardowskiego odeszła, ponieważ dax 
się ponieś́ pysze 1 dumie. Teraz musiaz od nowa budowad swoją s1 zę, zdany ty1ko na siebie.

Rysunk1 do "M1strza Iwardowskiego" wykonane sa na poplelatym tıe czarną kreska, a białe akcenty podkreślaja refleksy swlatła. Na rysunkach Okunia Twardowsk1 jest mzodym czlowiekiem o ostrych rysach 1 umęczonej twarzy. Jest uskrzydlonym aniozem. I postáb Twardowskiego w wierszu I smutry anjol okumia to ta sama osoba. Jest to przedistawienie cierplącego, nyobcowanego twórcy - Chrystusa - Boga 27 poświęcającego się dla nic nie rozumejęcych prostaczków.

Rysunek do śplewu czwartego /o tym, jak Twardowsk1 osiągmąz śwladomoś́ czynu I cholaz go przekazać lucizıom/ przedstawla Boga na chmurach, który błogosławi jasnymi promieniami leżęce gdzieśs w dole msasto. A splew ostatni /o tym, jak Twardowskiemu nie poWiodío się i musi zaczyná od nowal L.2ustruje rysunek anioła z zaclęta twarza, podwiniętymi skrzydzami i pięślami przyciśnfętymi do piersi.

Rysunk1 Okunı a sa wasną, specyfiomna interpretacje wierszy Staffa. Wspaniale oddaje $1 \mathrm{ch}$ klimat 1 atmosferę tajemniozosol: Są z godne z fabrła 1 potęuja jej wartości odmiennym sposobem interpretacjl fragmentów, których ale moḱna opowledzles, tych, które są claglem 11lozoficznych przemyśleń, m1styoznych wniosków poety \pm jego bohatera. Rysunk1 uzupezn1aja tekst symbol1czny posługując sie wzasna symbolike dla wyrażania Identycznych tresol. I.1.e.

Symbol1zm, głownie francuskiego rodowodu, nie byz jednym prądem, jakI rozwijaz s1e w epoce Mzodej Polsk1. Za1nteresowania twórców obracały sie równieź wokó idel stworzenla sztuki narodowej, wolnej od obcych wpływów, bazującej na rodzımym folk10rze.

Przykładem realizacj1 postulatów vspomnianego kierunku jest "Bajka o Kasi I królewiozu" 28 Lucjana Ryala z 1lustracjami Stanisława Dębickiego. IsIażka ta kączy w soble elementy sztuki ludowej z manierą plastyki mzodopolskiej, czyli odejściem od rea1istycznego, światłoclenıowego rysunku. Jest w istocle doskonałym poxązeniem styıu rysunków, maniery wiersza, formy graficznej I zarazem lekką zabawą. $w$ smutną rzeczyw1stośc. Najlepiej moga to zobrazowab Iragmenty wiersza oraz przeznaczone do nich I Iustracje: 


\begin{abstract}
"Nie miała Kasia ofoa an1 matkl jeno miaxa oczy jako dwa bławatki, Usta jak dwie wínín e, Liczka jak dwie zorze

I na służbie była Kasıa we królewskim dworze.

oj Kasıu, Kasıéko!"
\end{abstract}

Zwrotkę 11ustruja dwa rysunk1. Jeden przedstavia małą, zabiedzonq, vusç Kasıę $z$ węze łkıem $w$ ręku, w niebieskıej spódnı cy w krat kę, okutanę w ogromną, kraclastą chustę. Kasia ma plekne szafirowe oczy. Na drugım jest brama do królewskiego dworu. Ciemne, szafirowe niebo jako tło, czerwona cegła, złote ozdoby na bramie 1 kwitnące wokóz róże potęgują wrażenle bogactwa 1 wspaniałośc1. Na dworze Kasia clężko pracowała marząo o królewıczu. Gdy wyjeżdżał na polowanie, patrzyła za nim ze strychu. I Iustracje do tego fragmentu przedstaw1ają: jedna smutnę buzlę Kas1 wyglądającej przez maleńkie oklenko w dachu, a druga królewicza jadącego na polowanle. Królewicz ubrany jest w biały strój haftowany zlotem /parzen1ce, lampasy na spodnlach, złote lamówk1 wokól peleryny/, na glowie ma czerwoną krakuskę. Jedzie na ogromnym czarnym koniu, obok biegna psy. Strzemiona, uzda, wodze konia 1 wlosy królew loza są z lote.

Dalej wiersz opowlada o tym, jak Kasla poblegia do lasu za królewiczem. On postrzel1x ją, myśląo, że to jelé́ miga między drzewami 1 kazał wezwać lekarzy wtedy, gdy Kas1a leżała w kałuży krw1. Ona jednak nie chclała an1 1ekarza, ani złotego p1erśc1enia I korali Jako wynagrodzenia za krzywdy; cholała tylko, aby królew1cz pocazowaz ją, dopók1 jest jeszoze żywa.

Ostatnía zwrotka teź jest 1lustrowana. Na t le ogromnego, czerwonego słońca sledzi na ziemi Kas1a, a królewicz klęczy, obejmuje Ją 1 caß̌je. Kasia ma na soble nlebieską kraclasta spódn1ce, a królewioz bilazy strój ze złotymi ozdobami /hafty, podeszwy u butow, korona/.

Cała książka złożona jest czoionką 60-punktową, naśladująǫ̧ ręozne plsmo kaligrafıczne. InIcjaxy oraz maze elementy zdobnioge odbito czerwoną farbą. Do druku 1lustracji uży to nlewielu kololu, ale odpowiednie rozjaśnienle intensywnośc1 barwy lub nakoźeme jednej na drug̨ daje odpowiedni efekt. Kolor niebieski /ultramaryna/ daje intensywny odcleń szaflrowy; czerwony rozjasnlony Jest to róż; zupe łnie nlezależny jest kolor zloty. Odole- 
nie ozern 1 wpadające $j$ w granat lub flolet uzyskano

mieszając farbe czerwoną i niebieska. Z lota farba podkreśa pewne elemen-

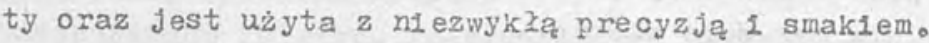

Formą 1 tresclą wiersz przypomina ludową balladę. Ilustracje przedstawiaja dwoje dzleci. 6-8-letnia dziewozynka jako uboga slerota jest ubrana $w$ bjedne szatk1. Natomiast królew1 cz $/ 10-12$ lat/ nosi stylizowany strój góralski i czapke krakowską zdobione zlotymi elementaml. Z Zota farba szczególnle wyraźnle podkrésla bogaotwo 1. wysokie urodzenle królewicza. Jej brak na rysunkach przedstaw1ajęcych Kasıę potęguje wrażenle jej ubóstwa. Postacie dziec1 są przetworzeniem motywów ludowych zgodnych z treścią wiersza, a raczej z jego stylem. Fakt, że bohaterani l lustraoj1 są dzlec1 1 że ksiązka jest drukowana czclonką 1mitująca pismo ręczne, wskazuje na stylizację ksiązk1 dzlecięcej - chod zastosowanie takiej oprawy graflcznej nie wynika z treso.1 wiersza, lecz jest jego dodatkowa 1nterpretacją. Ponadto książka ta zašuguje na mlano eleganckiej i nowoczesnej, w której wszystk1e elementy tworzą zwartą, spojną strukturę semjotyozną. I. 2.a.

Innym sposobem 1 lustrowania poezj1 byz odpowlednl dobor rysunicow, fotografil itp. wprowadzajacych czytelnika $w$ klimat utworów, nle beqdąoych jednak 1 Iustraoja. Rysunki i fotografie cechowaka zgodnosé $z$ atmosfera wierszy, gxowna loh zaś funkojt była ozdoba ks1ężk1. N1e zastepowały jak1egoś konkretnego fra.mentu tekstu - niektóre z nich stanowiky wstep, wprowadzenie historyczne lub tematyozne, ale nie odpowiadaly dokzadnie treśc1 wiersza. " tym wypadku też zachodzi pewnego rodzaju zgodność semiotyczna tnlędzy 1lustracją a wierszem, nle jest ona jednak tak sciska, jak w poprzedni ch przykladach. Poniewaź tekst nie jest tak mocno zwięzany z 1 lustracja, często wykorzystywano w tomikach tej grupy rysunik1, które wczesniej powstazy do innych utworow, a ao tych pasowazy waśnie kl1matem 1 stylem.

Najbardziej zwartym semiotycznie tomikiem jest th zbior wierszy Maryl1 Wolskiej "Z ogni kupalnych"29. "W ks Lążce panuje idealna harmonia między treście wierszy a charakterem ozdób 1 fotoBrafil. Strofy mów1ą o bóstwacn starosłomiańskioh; o kap łance wzywającej bogów na pomoc, bo sama nie zdola obudzí́ drzemíacej w Iudziach siły I odwagi; o dzlewozynie podpalającej swój stos 1 nie żałującej anI ycla, aní marzeń; o pożegnaniu przemijają- 
cego boga Lela ze spotkaną przypadkowo dziewozyną; o zakochanej dzlewczynı żalącej się przy ognısku na bogow. Tomik zdob1ą w1n1etk1 - ormamenty WKadys kawa W1tw1ok1ego będace jakby przetworzen1em, uwspółcześnienlem geometryoznych motywów słow1ańskich, p1sma run1czmego, swastyk1. Ilustracjam1 wprowadzającym1 w śwlat panteonu słoviańsklego sq̨ ponadto fotografle figurek bogów. Pogążk1 bogów: Radegesta, Morany, Le la I Trygława wykona ła Mary la Wolska.

Franciszek Namysłowsk 1 wydaz z biór p1sni religijnyoh "Magdalena Swięta" ${ }^{30}$. Sa to dewocyjne pleśni mające na celu szerzenle kultu sw. Magdaleny. Zdoblą je winletk1 stanowlące symbole rel1gijne/baranek, ryby, ręka z kielichem, główk1 an1ołów, Inicjal "II"/. I Iustracjam1 są reprodukcje obrazów przedstaw1ajacych św. Magdalenę w róźnych scenach z jej życia - pokutującą, u stóp Jezusa, u grobu po zmartwychistaniu Chrystusa. Pod każą reprodukcja została umieszozona informacja, w którym kościele znajduje się dany obraz. Obrazy nle stanowią 12ustracjl do poszcze gólnych pieśn1, ale wpronadzaja czytelnika w atinosferę kuztowę.

Rysunkt przedstawiające krajobrazj z godne z kl1matem wierszy o przyrodz1e, zmı̇nach w życ1u, porach roku, saúotnośc1, pożegnanıa, miłośc1, Eórach, ws1 1 jej dol1 pojaw1ają s1ę v "Poezjachn31 WitoIda Dzierżanowskiego. Realistyczne 1Iustracje wykonane przez Teodora Z1omika odblegają od treśl vierszy, sa jednak utrzymane $w$ loh kl1macle. N1e 11123 truja, ale poglęb1aja nastrój. Zostały umieszczone przed niektóryni utworan1. Wygląda to tak, jakby mybrano rysunki z pejzażem do wierszy, w których krajobraz /ozy to rzeczywisty, ozy symbol1czny - np. El sé jak las, jak jezioro, jak łąka/ jest najnaznıjejezy. Nie pojaw1ają s1ę natomiast przy tekstach op1sujących jakieś zdarzenia.

Tomikiem, w którym panuje rzeczywista zjodnosé wierszy /miejs ce lch powstania, op1sywane krajobrazy/ z treśc1q zdoblących je ryoin jest zbiorek Józefa Kośolelsiciego "Co mi Tatry dały?"32. Dw1e 11tograf1e wykonał do nich Leon Wyczółkowsk1. Sq to:widok Iit : cha oraz w1dok Morskiego Oka w kierunku Czarnego Stamu. Występuje tu zatem niewątp liwa zgodnoś́ tresci zawartych w wierszach 1 treśl rysunków wprowadzającyoh w atmosferę gór. Panuje natomiast absolutna niezgodność fortuy. Wiersze brzmią np. tak: 
"Na szczytach clsza śn1

Uroki sennych dn1,

A z góry pzynje czar,

Że sen najlepszy dar.

0 utul serce w sen,

Najlepszy ze snow ten:

że kiedyś jaik te sny

Rozp zyniesz sie i ty".

Wiersze mające niewlelka wartosó artystyozną zdobione sa rysunkaml wlelkiego artysty, wykonanymi, po mistrzowsinu. Iitografle zawarte $w$ tomiku stanowia samodzielne dzieza satuki. Grafiki wyczólkowskiego zmakom1cle keczę nastrój poezjl jako takjej - ze wspan1aza 1 groźmę przyrodą Matr.

I.2.b.

Jako samodz1ejne dzle 2ka można potraktowá takze rysunk 1 Antonjego Gawińskle zo do "pism" 33 fintonlego Szamaleransklego. Wien sze sa waniosie, patetyczne, o tematyce-relig1 fnaj. Są to żarliwe wyznania wiaxy wi Boga 1 dażenia do niego. Ilustrujes te poeaje umieszczone przed poszcze gólnymi cykiam1 rysunk1 przedatawlająoe pleknych an1oxów. Jeden gra na harfie, lnny - symbolizujący Sąd - wyclesa miecz z pochwy; nastepny patray zada1wiony 1 zamysiony. Rysuntet u.zupexnlają zawartosé tomiku o dodatkowe akoenty nie uwzglednione przez poeteg $w$ wienszach.

Podobny charakter - uzune rniamle zblorún wlenszy dodatkowymi treßciami maje opracowanla grapiczne viektórych antologil poezji.

"yoúr wierszy "Polska piesh́ milosna" 34 dokonany przez Jana Iorentow1cza 1justrowny jest reprodukcjani znanych obrazów po1skich malarzy. Antologla zawlera poezję nizosma począwszy od anonimowych plesni ludowych, przez utwory Jara Kochancwskiejo, Adama Hoklewioza, Juzlusza Szowackiego, aż do Leopolda Stafia, Bolesława Leśmiana, Komela Kakuszyriskie fo i wle lu 1nnych. Do ozdoby tomu wykorzystano między 1nnym1 obrazy: Artura Grottgera "p ożegnamie", Jana Natejk1 "Zygmunt 1 Barbara", Wojolecha Kossaka "Uzan 1 dziewezyna", Henryika SIemradzikie zo "Idy1za", Jacka Vialczewskiezo "Śmieré Jienai".

Podobnie 11ustrowana jest antolog1a "ZiemLa polska w pieśn ${ }^{35}$, także opracowana przez lorentow1cza. Tym razem ukxad wierszy nie jest chronologiczny, jak poprzedn10, a2e tematyczny. W1ersze zebrano $w$ k11ku. grupach: pory roku, Tatry, las, drzewa polskie, 
jezlora, polsk1e rzek1, wiersze o Warszaw1e. W tym wyborze wykorzystano utwory wielu poetow różnych epok, ale przeważaja utwory współczesne. Układ reprodukcji dopasowano do określonych tematyoznle miejsc w ks1ązce. Wśród wykorzystanych reprodukcj1 zmajdują się takie jak: Józela Chełmońsklego "Orka" - do wieszy o wlob́nie, Henryka Weysenhoffa "Na moczarach" - do wierszy o lec1e, Juliana Faxata "O zachodz1e" - do wierszy o zim1e, Wojclecha Gersona "Tatry" - do wierszy o Tatrach w porze letniej, Apoloniusza Kędzlerskiego "Brzeg1 Naxw1" - do wierszy o rzekach polskich, dwa obrazy Canaletta "Warszawa od strony Prag1" 1 "Krakowskie Przedmieśle" - do wierszy o Warszawie.

W obu antologlach reprodukcje obrazów, które przeclez powstazy bez zw1ązku z tekstem, stanow1ą nie tylko wprowadzenie do tenatyk1 utworów. Są także jekby jeszoze jednym głosem przedstaw1clel1 sztuk1 dodanym do tonu zawierajęcego 1 nne glosy na ten sam temat. Ob1e pozycje sa znakowitymi przykładam1 współistnienia 1 wzajemı ơ uzupełnıania słę dwóch sztuk, tak zdawałoby się różnych - malarstwa i poezji.

I.2.c.

Zasada 1ntegracj1 sztuk wysteppuje także w dzle lach zdoblonych rysunkam 1 autorów tekstów 11terackich. Sę to dzıeła, których 11ustracje nie były 1nsp 1rowane tekstem. Rysunk1 są wyntkiem plastycznego /obok 11terackiego/ talentu poety 1 p13arza. Przedstaw1azy ozęsto wraźen1a z podrózy, jak w przypadku jul1usza słowackiego lub portrety ośbb znajomych, rzé́b 1 karykatury, jak w przypadku Cypriana Kan1la Norw1da. Rysunk1 w "Dzlezach"36 Sxowacklego 1 w "P1smach zebranych"37 Norw1 da nie 1lustrują tekstów, nle wprowadzają cayte inika w klinat poszczejólnych utworów, ale sạ dodatkowym uzupeinieniem spuśc1zny autora. Nie ma tu zgodnośc1 między tresola rysunku I tresclę utworu pisanego. Ale tak jak nie można porównywá́ z godnośo1 treślowej różyoh wlerszy zawartych w Jednej ksiązce lub obrazów wiszących na jednej ścianie, tak sano nie można tego robsé w przypadku wierszy, dramatón, prozy 1 rysunkow np. Norwida, objętych jednym tomem w wya1ku dziazalnośl wydawcy. Jednakże zgodność senlotyozna występuje tu rómniez. Jest nią wspóxistnienie obok sieb1e przejawów różnych sztuk pow 1ązanych osobowośc1ą autora, wyrażającego odmiennym 1 "językamil bliskie sob1e 1 dee. 
I. 2.d.

Elementam1 graf1cznym1, których jedynym zadanlem było zdoblenie książk1, są winletk1, bordiury, iniojały'. Często byzy one the zym1 IIustracjam1 wprowadzającymı w atmos fere Iub treś w werszy.

Rysunk1 Kazlmierza S1chulskiego do "Plosenek Z1elone go BalonIkall 38 są, podobnıe jak wiersze, żartobliwe, lekko skandal1zujące, skłanıające do traktowania ksıążk z przymrużenı́m oka. Winietki, czy raczej przerymiki Sichulskiego dodają plkanteri1 1 tak już doś́ frywoznym tekstom Tadeusza Boya-żeleńsk1ego, mimo że lah nie I lustrują.

Specyficzna winietę wykonax Jan Bukowsk1 do "Bogurodzicy" zamleszczonej w "Antoloj11 polskiej"39 zebranej przez Wladysława Bezzę. Opracowanie graficzne wiersza stylizowane jest na gotyck1e. Duky inicjaz "B" zawiera na górnym brzuszku rysunek Watkí Boskiej Czq̨atochowskiej. Wokbl tekstu clagnie sie bogata floratura w kolorach czarrym i rudobręzowym. Rudobrązowe są takse plexwsze 11texy poszczególnych wersów. Caza oprawa plastyczna "Bogurodzlcy" swiadczy o dużym p1etyzmle dla w1ersza, a takíe - wyczuciu sty21styk1 gatunku przez Jana Bukowskego.

"iniety znakomicie wpronadzające w kimat utworu znajduję się w bajce Liari1 haricowskiej "O królu węíu 1 Jasku"40 zdobıonej przez Antoninę Dunin. Oprócz 1lustrujęcych treść rysunków na wszysticlch stronach powtarzaja się trzy winjetki przedstawiajęce fragmenty panoramy Tatr. Zostazy ułożone w takí sposób, że czytelnik ma zludzenie przesuwającego się przed oczami nieskończonego 1 zmiennego zaícucha górskiego. Wśód czarnych, potęźnyoh Tatr rozgrywa sie akcja baśn1.

Zw1ązane z góram1 sa wiersza Józefa Kośclelsiklego "Preludia zakoplańsxie $n^{41}$. Ozdoblone zostaky przez W.K.P. ledwle widocznym1 jasnozlelonym1 przerywnikam1 przypominającym1 goralskie wycinanki w drewnie. Tego typu ornarient mie wrowadza żadnego nastroju, ale stwarza dodatiowe uzupelnienie caloscl. Wyolnank1 pseudogóralskie same $w$ soble są czymś w rodzaju preludium zakoplańskiego.

\section{I.3.a.}

Istnieje jeszcze jeden aspekt z godności semiotycznej. Jest to zgodnoś́ forny. W tym wypadku treść wiersza nie jest istotna. Vszystko zostało podporzadkowane jednemu zadaniu - maksymalnemu 
wydobyoıu pıękna $z$ przedmıotu, jakım jest ksıążka. Największe 1 nlewątpliwe sa tutaj zaskugi Staniszawa Wysplaísikiego. On rozpoczą ruch odnowy ks1ążk, a za nim poszli 1nni. Znakomi cle zostaxy opracowane graficanle przez isplańskiego "Poezjen"42 Iucjana Rydla, "W mroku gwlazd"43 Tadeusza Mlolńskiego czy "Z cykIu "1g1111"44 Stanisława Przybysz ewskiego. Nie ustępują 1m róknieź real1zacje graficzne tak1ch tomików, jak: "Usta mroku" 45 Wackawa Wledigera w opracowaniu autora ozy "Jeszczem wcląz pełen w1osny" 46 Edwarda Słońskiego zcioblone przez Zygmunta Kanińskiego, Apoloniusza Kędzierskle go 1 Tadeusza U Lanowskiego.

Zdobnictwo tego rodzaju by H1odej Polsk1. Ogromna w1ększość ksı̨̨żek zaopatrzona jest $w$ bardzlej lub malej realistyczno rysunki kwiatów, gałęzek, czasem krajobrazów, k1edy Indziej fantastycanych zwierząt /smok1, sty11zowane nletoperze, pająkl/. Winletik1 1 przerywik1 niczego nie lustruja, pozbawione se aspektu. zaaczeniowego 1 spelniają jedynie funkcję ozysto ozdobna. Sz elenentam zamizcymi monotonie strony. Jest to zgodne z kanonem estetyarnym epoks Niodef Polsk1, gloszącym postulat plękna codżennyoh przedmiotów, sztuk1 uzjtkowej, woornictwa przemysłowego.

I. 3.b.

Do tego typu /zgodność semlotyczna $w$ zakreale formy/ należy zalł czyć także kslożk1 pozbawione zupein1e ozaób. Bleganck10 rozm1eszczen1e tekstu na stron1e, scerok1e marginesy, odpowiedni dobór czclonek I papieru - to stahow1 zo o 1ch plęmie. Hoże nawet bardziej oddziaływało na wyobraźnię ozytelnika aiz kwiatowe przerywn1k1, nle zawsze dopasowane do tresc1 wierszy. Ks1ajk1 plękne typo graficznie to np. tomiki wierszy Wackawa Rolicz- Ifedera. Tu nic nie zaciemma trescl wierszy, ale tez nio $1 \mathrm{ch}$ nie tiumaczy. Ukzad kolumny tekstu, ozytelna ozclonka, szerokie marglnesy sprawiaje wrażenie przejrzystosc1. Wywozuja chę wz1ec1a tairlej ksıążh do ręki I sugerują, że sam wygląd

strony uzatw1 zrozumlenie niezatwych, symbolioznych wierszy Ro21cz-I1edera.

Tomikl tego poety, wydare w ostatniej dekadzie XIX wieku4?, otw1erazy niejako okres likodej Polski, tak jak zamykały ja tomik1 Leopolda Staffa ${ }^{48}$ wydane w ostatnlej fazle tej epok1. odb1te zostały na żeberkowym paplerze bardzo staramie, czysto, z dużę 110 śla sw1atza. Okzadke w tych księzkach stanow1 niebiesk1 
papier a granatowymi napisami 1 srebrnymi, delikatnym 1 ozdobami secesyjnym1.

Jest w nich to samo przesłanie estetyczne, co w edycjach wienszy Ro11oz-Iledera - dzlęk1 jasnoso1 1 przejrzystośl można tralić do czytelnika. $W$ ten sposob stwarza się pewien komfort odbicru poezji, której nle przesłania natłok ozdób - nawet zgodnych ze stylem epok1, ale nie zawsze z charakterem wiersza. II.1.

Niezgodnoś́ treści 11ustracj1 1 tresol wiersza

szczególnie wyraknıe przejawıa się w tomıku wierszy Edwarda Milewskiego "Kwitnące clera1e"49, zdob1onym przez Annę Granatykę-Ostrowską. Bogate bordiury ze sty $11 z$ wanyoh kwiatów przywozują z pamięcl obraz książi renesansowej, a to potwierdza zgodność formy z postulatami ruchu odnowy kslężk - powrót do najplękniejszego jej okresu - renesansu. Wykorzystanie motywow rysunku haftu judowe zo takze nie budz1 sprzeciwu - bylo bowlem z godne z postulatem sztuk1 narodowej. Natomlast treś́ w1erszy jest odm1enna. Mówlą one o walce o niepodjegzość I sprawiedliwość spozeczną; są patmotyozne, głoszą, że śnjerć w siusznej sprawie nie jest wygórowana ceną. Do podobnych, wierszy - waniosłych 1 patetyoznych - zupeinie nie pasują haftowane ludowe kwlatkl.

Trudro mówié o zgodnoscl treśclowej także w wypadku wierszy Kaz1rierza "roozyńsicıego "z zapatrzeń"50. Wiersze są barwne, plastyczne, żywo oddzıaływują na wyobraźnię, o tematyce typowej dia epok1/mizośb, pejaaź, teatr, romantyczne refleksje/. S bardzo polskie w stylu 1 op 1sywanyoh krajobrazach. Zdobla je xysunk1 Korına zaczerpnięte z "Chimery". Przedstawiaja one motywy japońsklej przyrody na winletkach w ksztalole roziozonyoh wachlarzy. Tego typu winietk1 nlewątpliwie zdobią ks1ężkę, ale kierują w niew laśc1wą stronę wyobraźnię czyteintka.

Antologia poetów polskich, zatytuzowana "Bard polsk1"51, równıé̇ stanowi przyklad braku zgodnoscl semlotycznej pod względem treśc1. Zdobiona jest rysunkami różych twórcow przełorau XIX 1 XX wieku - tak polskich, jak 1 obcych. Znalaziy sle tam między InnymI rysunki Edwarda Okunia wykonane do "Chimery" /"Król Kofetra" Jul1usa Zeyera/, Aubreya Beardsleya przeznaczone do "Salome" Oskara "ilide'a, rysunk1 Edwarda Słońskiego, którymi zdob12 wrasne tomik1, Efraima L1liena 1 wlelu innych. Zadaniem rysunków jest zdobienıe ksıążki, ale 1 ch flouratywny charakter po- 
woduje błędy w Interpretacj1 poezj1. Czytelnik odbiera w1ersz przez pryzmat rysunku uważanego za 1lustrację danego wlersza, który to rysunek przedstaw1a /a często 1 symbolizuje/ zupeznie inne tresci.

II. 2 .

Niez godnoś́ semiotyozna w zakresle formy polega nle tylko na różnicach styzu \& poziomu artystycznego wlerszy 1 1lustracji / jak w przypadku prezentowanego już zb1oru Józefa Koślelskiego "Co mi Tatry daxy?" z 11tografiami Leona Wyozólkowskiego/, a le także na nlezgodnośc1 stylu lub pozlomu artystycznego szaty graficznej z wymogamı kanonów 1 wzorów sztuk1 przełomu XIX 1 XX w1eku.

To nlepokojące zjawisko występuje nawet w twórozokc1 Stan1slawa Vysplańskiego. W1nletki przez niego zaprojektowane są rysunkain1 kwiatów, które nic nikomu nie mów1̨̨, nie infortują nawet, że dana książa jest tomikiem wierszy - bo 1dentyczne wystepuja w kslązkach będących zb1orami utworów prozatorsklch. Spe wyłączile funkcje zdobnıcza. Jeỉeli są odb1te na dobrym papierze, funkcja ta jest wówczas rzeczywiscie spełniana. Natomiast jeśli papıer jest 11chy, vitedy róże, plerwiosnki, osty 1tp. nie wykazują nawet zgodnosol formalnej. ze stylem epok1, jak np. w "Studiach 1 strolach"52 W1tolda Godlewsk1ego-Gozdawy zub "wyborze pism" 53 Mari1 Konopnickiej. Sprowadzone zostaly tu do rangl przeclętnych przerywnikó: z zasobu typografloznego drukarni 1 to gorszej Jakośl. Być może matryce używane do ich pow1elan1a szybciej uiegaly zniszczeniu 1 gorzej przelewaxy farbe na papier.

Nlezgodnośc formy 1 treśc1, zw zaszoza na tle epok1, przejaw1a s1ę w zb1orku Tadeusza U lanowskiego "Summa sumarum"54. Tresc1ą wierszy jest polemika poety z otaczająca so rzeczyw 1 tosc1ą. Znajdują sie tam wiersze o tematyce historycznej, wspobczesnej, moral1zatorsklej, fragmenty będące pochwała MIriama 1 fragmenty - Żydach. Ozdobami wykonanymi przez sanego autora piórkiem 1 tuszem sa powtarzające s1e, realistyczne, wypracowane ozdobnikl 1 przerywnik1. Przedstawlaja kwlaty, glowę whezmie, jeżozwierza, czyjó prop11. Niczejo nie 11ustrują 1 miczego nie zcob1ą. Są konserwatywne, statycane, wykonane bez polotu.

Takz opinie można mieć o rysunkach zam1eszozonych w tym tom1$k u$, ale wiadomo, ż $1 \mathrm{ch}$ autor $z$ dobrym skutklem potrafl 1 zdoblé toiniki poezj1 mzodopolskiej innyoh autorów. 
W okresie Młodej Polski dążenie do zgodnośl semiotyoznej /ohoc1aź tak nie nazywanej/ było jednym z najwaźnı ejszych kxyterlów estetycznych. Ksiazka miała stanow1ó spojną strukture, w której wszystkle elementy - słowo, obraz, typografla - by zyby powlązane 1 wajemnie od sieble zaleźne. Niełatwo było jednak zdobió poezje tak, aby były zachowane odpowiednıe zwlązki między tekstem, 1lustracją 1 drukiem. Wielu autorów szaty Eraficznej potraf1 ło rozwiązá ten probletn, ale byl1 to twórcy najwyźszej miary. Innı próbowali naśladowá́ doskonałe wzory, ale - jak to bywa z b1ernym 1 nieudo Lnym naśladown1otwem - rzadko udawazo 1m się wydobyé odpowiedni elekt.

Mlzodopolskie dążeme do integracj1 sztuk, widoczne wi tom1kach poezji, chociaz nie zansze w pelni udane w swej epoce, by 10 kontynuowane. Postulat harnoni1 różnych elementów ksıążk1 żywy jest do dziś. Wspóxoześni wydawoy rómieź dążą do połączenia w jednolitą strukture wszelk1 ch elementów składających sie na ksiązkę. Niestety, 1 dziś nie zawsze s1ę to udaje. Jednak wydawcy poezj1 moga czerpać wzory z doświadczeń młodopolskıch.

W znacznej mıerze dzlęk1 n:zodopolskiemu mohowi odnowy ksiązk1, przec1wstaw1ającerau się sztuce ubiegłych wieków 1 odrzucaJącemu stare kanony, dzisiejsze edyoje poezj1 są jasne, przejrzyste, pozbawione natłoku ozdób. Czasen Jednak żal, że tak dokładnie wyzwoliły się z 11ustracj1, winiet 1 ozdobników że niemal wszystkje toraki są jednakowo suche 1 rzadko proponuja ozytelnikow rozwiązania interpretacyjne wierszy przez graflke tak Jak to bywało w epoce Młodej Polskl.

\section{Summary}

The semiotio criterion is a principal one in the evaluation of tire book. On the turn of the 19 th and 20 th centuries this oriterion was also utilized/despite the fact the semiotic terms were not in use/ for evaluating the aesthetio value the book.

This article, on the example of Xoung Poland's volumes of poetry, tries to show interrelations between the contents of the poems, graphic side of the volumes and their editorial level. The examples are ordered in a schematic way which makes it 
possible to discuss the above dependenoles in various aspects: $1 /$ the harmony between the contents of the poems and the 112ustrations; 2/ the harmony between the mood of the poems and the ornamentation of the volume; $3 /$ the harmony of the form of the book of poetry with the style of the epoch.

Negatlve examples are also presented in order to show the lack of the synthesis of arts being the principal aesthetio goal of the Young Poland's epoch.

\section{Przyp 1sy}

1 Stanow1 to treś́ mojej pracy maglsterskiej "Edycje poezj1 w epoce Mxodej Polski" /ilarszava 1985/, napisanej pod kierunkiem prof. dr hab. Barbary Bieńkowskiej /maszyropis w Bibliotece Instytutu B1bliotekoznawstwa 1 Informacj1 Naukowej Uniwersytetu Warszawskiego/.

2

H.Walis, Sztuk1 I znak1. P1 sma semlotyczne, Paístwowy Instytut Wydawniozy, Farszawa 1983, s.116.

3 Tamie, s. 123.

4 Tamże, s. 127.

5 A.Oppman, Hıstorie o grzybowych ludkach. 12 obrazków kolorowych $\mathrm{z}$ w1 erszem, M.Arct, Warszawa /1911/.

6 M.Konopnioka, Na jagody!, Gebethner 1 Wolff, Warszawa, Krakow /1903; 1913/.

7 M.Konopnicka, 0 Janku Wędrownlczku, H.Aret, Warszawa /1892/.

8 M.Konopnicka, Wojna, Gebethner 1 Sp., Krakón 1913.

9 Z.Gordzlazkowska, Bbckl1n w poezji, Gebethner 1 Wolff, Warszawa 1911.

$10 \% . B u k o w i n ́ s k 1, N a$ greckiej fal1. Poemat I1ryozny, Gebethner 1. Wolff, Krakow, Warszawa 1905.

11 K.Lubecki, Izustrowane sonety rzymskie, Gebethner 1 Wolff, Krakow /1907/.

12

A.Mlckiewicz, Konrad Wallenrod, H.4ltenberg, Iw Sw /1890/.

13

L.Finke 1, P1eśń Ległonów, H.A1tenberg, Lwów 1894.

14 J.Słowack1, Dzieła, Drukarnia "Estetyczna", Warszawa 1909. 
J.U.NIemcewicz, Splewy historyczme, Nakz. Niaclerzy skiej, Lmów 1895.

16. S.Jachowi cz, BajkI I powiastki w I Lustrowane J edycj1, druk W.Korneckiego, Kraków 1890; / ok. 1900/.

17 W.Beiza, Katechlzm polskiego dz1ecka, wyd.3 - H.A.tenberg, Lwów /1902/; wyd. 6 - Towarzystwo Szkozy Lladowej, Kraków 1913.

18 $11910 /$

J.S łowack1, 0 Janku, co psom szyz buty; M.Arot, Warszawa

19

L.Ryde 1, Pan Twardowsk1. Poemat w XVIII pleśn1ach, B.Wende $1 \mathrm{Sp}$. , Kraków, Warszawa 1906.

20

Vi.Z1elińsk1, Czarodz1ejskie w1ano, Gebethner Warszawa; Gebethner 1 Sp., Kraków 1909.

i. Wolfe,

21

M.S.Lewin, Don Juan redivivus. Poemat oynıozny, nakł. W. Wiedigera Krakón 1908; I. Wende $1 \mathrm{Sp}$. , Warszawa 1912 .

22

E.B1eder, Poezje. Ser1a II, nakz. D.E.Friedle1n, Kraków B.Wende 1 Sp., Warszawa 1901.

23 w epoce Hzodej polski wędrówka, tuzan1e sie 1tp. by zy symbolem ludzkie-o ay cla; słonce - to symbol przyszzośc1, nadalel, powstawanla noweso; ślenleo/tu czlowlek zakrywający oczy/ oznacza niemoźność ujrzenia prawdy albo nieumiejętność adaptacjl do rzeczyw1stoś1 wobec przeozucia prawdy. Zob. M.Podraza-Kwlatkowska, Synbolizm I symbollka w poezjl Młodej polsk1. Teoria 1 praktyka, " ydawn ctwo L1terack1e, Krak $6 w 1975,5.148-153$, $158-160$.

24 Tamíe, s.54.

25 J.Kasprowica, M1zoś, /Ks1ęgamıa Polska/ Iwów 1902.

26 L.Staff, Mistrz Twardowsk1. Pięć śp1ewbw o czyn1e, /Księgarnıa Polskal, Lwów, Kraków 1902.

27

II symboliamie mzodopolskim ozęsto utożsantano Chrystusa 1 Do jajo twórce, Chrystusa 1 Bo ja jako postaó wiedząca więcej niz ilm1, poświęcajaca sle dia przecletnych, szarych ludzi 1 wzgardzoną przez nich. "Is li.Podraza-Kwiatkowska, op.cit., $5.385-411$.

23 L.Rydel, Bajka O Kas1 1 królew1ozu, nakz. Towarzystwa Wydawniczego, Lwów/1903/.

29

H.Wolska, Z ogni kupalnych, Skole-Strozka: /b.w./ 1904; Kslęgarnla Polska B.P ołonlecklego, Lwów 1905.

30 F.Namys lowsk1, Magdalena Swlęta. Plesni religljme polskie 1 ustrowane, druk. "Czasu", Kraków 1913.

31 W.Dzierżanowski, Poezje I, S.Demby, Warszawa 1903.

32 J.Kosclelsk1, Co mI Tatry dały? Preludia, sonety, Gebethner

$1 \mathrm{Sp} ., \mathrm{Kraków} 1905$. 
33 A.Szandlerowsk1, P1sma, Gebethner 1 Wolff, Warszawa 1912$-1914$.

34 Polska pleśń mıłosna. Antologia, Gebethner 1 Wolff, Warszawa, Krakow 1912.

35 Zlemia polska w pleśnı, Gebetnner 1 Wolff, Warszawa, Lub11n, Kraków /1913/.

36 J.Słowack1, Dzieła, nakz. Ksieggarnı Polsk1ej, Lwów 1894.

37 C.K.Norw1d, P1sma zebrane, nakł. J.Mortkow1cza, Warszawa, Kraków 1911.

38 T.Boy-żeleńsk1, Plosenki I fraszk1 Zielonego Balonika, Gebethner 1 Sp., Kraków /1908/

39 Antologia polska. Wybór ze 100 poetów polskich, H.Altenberg, Iwów; W.Anczyc, Kraków 1906.

40 M. Markowska, 0 królu wężu 1 o Jaśku. Baśn tatrzańska, Księgarnia Polska J.sikorskjej, Warszáwa 1909.

41 J.Kośolelsk1, Preludia zakopiańskle, druk. P.Laskauera $1 \mathrm{Sp}$, Warszawa 1903.

42 L.Ryde 1, Poezje, nakł. D.E.Frledle1na Krakơ;; E.Vende 1 Sp., Warszawa/1901/.

43 T.M1c1ńsk1, W mroku gw1azd, Gebethner 1 Sp., Kraków 1902. 1899.

44 s.Przybyszewsk1, 2 cyklu Vl1 g1 I11, Ks1egarn1a Polska, Lwow

45 W.WLediger, Usta mroku, Kslegarnıa Narodowa, Lwów /"Iz1s"/; W.Ariozyc i Sp., Kraków 1905.

46 E.Słońsk1, Jeszczem wc1ąż pełen w1 osny, P.Laskauer $1 \mathrm{Sp}$. Warszawa 1909 .

47 W.Rol1 cz-Lieder, Moja muza, W.Anczyc I Sp., Kraków 1896; Wiersze III W•Anczyc i Sp., Paryż, Warszawa, WIedeń, Kraków 189a Hierszów ksieg1 plerwsze, drugie i trzecle, Sp.Wydawicza, Kré-
ków 1898.

48 I.Stafi, Sny o potędze, wyd.2, Polska Ks1ęgarn1a, Lwów; E.Wende $1 \mathrm{Sp}$., Warszawa; W.Anczyo 1 Sp., Kraków 1905; Ptakom n1ebiesk1m, wyd.2, Księgarmia Polska, Lwów; EoWende $1 \mathrm{Sp}$., Warszawa; W.Anozyo 1 Sp., Krak ów 1910; Eabędź 1 11ra, Księgarnia Polska, Iw $w$; B.Wende i Sp., Warszawa 1914.

49 E.M1lewsk1, Kw1tnące clernle, J.Mortiowicz, Warszawa /1907/.

50 K.Wroczyńsk1, $Z$ zapatrzeń, E.Wende 1 Sp. Warszawa; W.Anozyo $1 \mathrm{Sp} \cdot$, Krakón 1908. 1909.

51 Bard polsk1. Album poetów polskich, L.Idzikowsk1, Kı Jów 
